\title{
THE IMPLEMENTATION OF CHARACTER EDUCATION ON ISLAMIC RELIGIOUS EDUCATION SUBJECTS AT SENIOR HIGH SCHOOL 1 BENTENG, SELAYAR
}

\author{
Ponno, Saprin, Muh. Rapi \\ UIN Alauddin Makassar \\ Jln. H. M. Yasin Limpo No. 36 Samata, Gowa \\ Email: abdulponno123@gmail.com; saprin.uin@gmail.com; \\ mrapi@uin-alauddin.ac.id
}

\begin{abstract}
This article discusses the Implementation of Character Education in Islamic Religious Education Subjects at Senior High School 1 (SMA 1) Benteng, Selayar. This study uses qualitative research by analyzing existing information data, based on facts in the field. Data obtained through observation, interviews, documentation and drawing conclusions so that they can unravel the problem completely in accordance with the problems discussed. Implementation of planting character values to students. So the most important thing is the teacher's expertise in internalizing the character education. into all aspects of subjects that will be given to students in schools because character education is one of the main elements of religion that cannot be separated from Islamic teachings. That is why character education is integrated in Islamic Religious Education subjects.
\end{abstract}

Keywords: Implementation, Education, Character, 


\section{INTRODUCTION}

The application of character education from an early age can provide solutions to the problems faced by the world of education, namely the decline in moral values. Through the application of character education, education in Indonesia can produce alumni who are superior, accomplished, intelligent, faithful, pious, have noble character and have expertise in their fields and have character. As stipulated in the Law of the Republic of Indonesia Number 20 of 2003 concerning the National Education System in article 3, it is described as follows:

"National education functions to develop capabilities and shape the character and civilization of a dignified nation in the context of educating the nation's life, aiming at developing the potential of students to become human beings who believe and fear God Almighty, have noble character, are healthy, knowledgeable, capable, creative. , be independent and become a democratic and responsible citizen". ${ }^{1}$

In the context of national education, standards are needed that must be achieved within a certain period of time to realize the goals of national education. Strategic steps can be achieved through various activities in the educational process, especially the inculcation of character values to students held in schools.

Instilling character values to students who are not only intelligent but also have character or noble character in everyday life. The application of internalization of character education values to students through subjects at school. One of them is through the subject of Islamic Religious Education in schools, it is very possible to instill character values to students who shape students to be superior, intelligent, and have character.

\footnotetext{
${ }^{1}$ Republik Indonesia, UU RI No 20 Th 2003 SISDIKNAS, p. 8.
} 
Senior High School, Benteng, Selayar is one of the leading schools in Selayar Islands Regency which is implementing character education in Islamic Religious Education subjects. To specifically examine the implementation of character education in Islamic religious education subjects at the school, conducting initial observations and interviews at the research location.

The process of instilling character values into students is not only through certain learning but is integrated into all subjects in the intracurricular and extracurricular learning process. Through strengthening character education, it can improve the quality of graduates through soft skills competencies and internalize character values in daily life so as to realize the vision of the school, which is to create an environmentally sound school that produces human resources with noble character, professional, spirited entrepreneurship, and able to compete in the global era.

The application of character education at the school is seen as very helpful for students in developing their character by internalizing character values into the learning process, especially in Islamic Religious Education lessons. Character education is a process of giving guidance to students to become fully human beings with character in the dimensions of heart, mind, body, taste and intention. Character education can be interpreted as moral education, values, character education, moral education, character education.

From this description, it needs to be studied more deeply to find the formalization of the implementation of character education in schools. This is what encourages and inspires the author to conduct research in the form of a thesis on the implementation of character education in Islamic Religious Education subjects at senior high school, Benteng, Selayar, considering that character education is very urgently implemented in formal education in schools to create students with character. 


\section{THEORETICAL FRAMEWORK}

Character education meant in this case is the process of transforming the values of life to be developed in the personality of a person or student so that they become one in the behavior of that person's life. Character education involves moral education, value education and also religion, meaning that moral education serves as the basis for character education, in the form of individual moral decisions, namely whether he will be a good human being or a bad person, related to one's mind, in the form of decisions, choices that free and responsible.

Furthermore, value education is related to the values of character, manners, manners in society and morals, serves to help students recognize, realize the importance and live up to the values that are appropriate and should be used as guides for human attitudes and behavior, both individually. as well as together in a society, as well as religion that is used as a human basis for living guidelines and behaving in accordance with the rules of its teachings.

\section{Strengthening Character Education}

From various news cases, it can be seen that Indonesia is experiencing moral problems. Therefore, to overcome the problem of the decline in the culture and character of the nation, many parties believe that education still plays a very important role. Education is considered as a preventive alternative which is expected to develop the culture and character of our nation's young generation in various aspects of life, which can minimize or reduce the causes of various problems of cultural decline and national character. ${ }^{2}$

Strengthening character education is not a new policy at all because since 2010 character education in schools has become a national movement. Many practices have been developed by schools, but there is still a lot of homework to

\footnotetext{
${ }^{2}$ Amat Jaidun dkk, Model Pendidikan Karakter di SMK Melalui Program Pengembangan Diri dan Kultur Sekolab (Yogyakarta: Jurnal Pendidikan Teknologi dan Kejuruan Volume 22).
} 
be done to ensure that the process of cultivating character values runs and is sustainable. In addition, a policy is needed that will become the basis for the formulation of more concrete steps so that the cultivation and cultivation of the main values of forming the nation's character can be carried out effectively and thoroughly.

Presidential Regulation Number 87 of 2017 concerning Strengthening Character Education which is stated in Article 1 that Strengthening Character Education, hereinafter abbreviated as PPK, are:

"The education movement is under the responsibility of the education unit to strengthen the character of students through harmonization of the heart, taste, thought, and sports with involvement and cooperation between education units, families, and the community as part of the National Mental Revolution Movement (GNRM). )".

The PPK movement can be interpreted as the embodiment of the Mental Revolution Movement as well as an integral part of the Nawacita. The PPK movement places character education as the deepest dimension or core of national education so that character education becomes the axis of the implementation of primary and secondary education. Furthermore, the KDP movement needs to integrate, deepen, expand, and at the same time harmonize the various character education programs and activities that have been implemented until now. ${ }^{3}$

Many education units have implemented best practices in the application of character education. The impact of this application is that there is a fundamental change in the education ecosystem and the learning process so that their achievement also increases. The PPK program wants to

${ }^{3}$ Kemendikbud, Panduan Pengembangan Rencana Kerjo Sekoolah (RKS) dan Rencana Kegiatan dan Anggaran Sekolah (RKAS). Jakarta: Direktorat Pembinaan Sekolah Menengah Pertama, 2015. 
strengthen the character building of students carried out in schools.

Strengthening class-based Character Education can be done in various ways including:

a. Integrating the learning process in the classroom through curriculum content in subjects, both thematically and integrated in subjects.

b. Strengthen classroom management, choice of methodology and evaluation of teaching.

c. Selection and use of appropriate learning methods in accordance with the material, class conditions and values to be conveyed. ${ }^{4}$

In the context of implementing this program, character education as mentioned above has eighteen values, then five main values are taken which are the focus of the Strengthening Character Education program. The five values are Religious, Nationalist, Independence, Mutual Cooperation and Integrity. ${ }^{5}$

The fifth grades character of the main nations are referred to are as follows:

a. Religious

Values reflect keberimanan religious character of the God who Maha Esa are manifested in the behavior of carrying out the teachings of religion and belief are embraced, respect for differences of religion, upholding the tolerant attitude toward the practice of religion and other beliefs, live in harmony and peace with the followers of religions other. The value of this religious character includes three dimensions of relations at once, namely the relationship of the individual with God, the individual with others, and the individual with the universe (environment). The value of this religious

\footnotetext{
${ }^{4}$ Agus Wibowo, Pendidikan Karakter; Strategi Membangun Karakter Bangsa Berperadaban (Yogyakarta: Pustaka Pelajar, 2012), p. 20.

${ }^{5}$ Tim PPK Kemendikbud, Konsep dan Pedoman Penguatan Pendidikan Karakter Tingkat Satuan Dasar dan Sekolah Menengab (Jakarta: Kemendikbud RI, 2017), p. 5.
} 
character is shown in the behavior of loving and maintaining the integrity of creation. Sub value religious among others the love of peace, tolerance, respect for differences of religion and belief, firm establishment, confidence, cooperation among religions and beliefs, antibully and violence, friendship, sincerity, do not force the will, love the environment, protect the small and isolated.

b. Nationalist

Values nationalist character is a way of thinking, being, and doing the show loyalty, awareness, and appreciation are high on the language, environment physical, social, cultural, economic, and political nation, placing the interests of the nation and country above the interests of himself and his group. Nationalist sub-values include appreciation of the nation's own culture, maintaining the nation's cultural wealth, being willing to sacrifice, excelling, and achieving, loving the homeland, protecting the environment, obeying the law, discipline, respecting cultural, ethnic and religious diversity .

c. independent

The value of independent character is an attitude and behavior that does not depend on others and uses all energy, thought, time to realize hopes, dreams and ideals. Sub values self-contained, among others, work ethic (hard work), a tough resilient, fighting spirit, professional, creative, daring, and become learners throughout life.

\section{d. Gotong Royong}

Value character gotong royong reflect the actions appreciate the spirit of working together and shoulder to shoulder resolve the issues together, establish communication and friendship, give relief / aid to people who need it. Sub value gotong royong among others respect, working together, inclusive, committed on the decision together, deliberative consensus, mutual help, solidarity, empathy, antidiscrimination, anti- violence, and the attitude of volunteerism 
e. Value of integrity character

Integrity character values are values that underlie individuals to always be someone who can be trusted in words, actions, and work. Examples of the value of character integrity among others honest, anti -corruption, exemplary, bear responsibility, and others. The five character values are interrelated which develop dynamically to form a complete personality. ${ }^{6}$

Strengthening Character Education is a program launched by the government as a series of activities as the realization of a policy. In carrying out a policy and implementing it, it is necessary to plan a program, its implementation and also an evaluation of the program.

So in this case character education means not just teaching what is right and what is wrong, more than that character education instills habits ( habituation) about what is good so that students are educated to understand ( cognitive domain) about what is right and wrong, able to feel (affective domain) good values and able to do it (psychomotor domain), so that the component of character education must involve not only the aspect of "knowing the good" ( moral knowing), but also "desiring the good" or "loving the good" ( moral feeling) and "acting the good" ( moral action).

While the purpose of character education in the perspective of the Koran itself is actually more emphasized on getting someone to practice and practice good values and stay away from bad values and is intended so that humans know how to live, or how to live.

\section{RESEARCH METHOD}

This research uses field research (descriptive qualitative field research). The type of research in the preparation of this thesis

${ }^{6}$ Kemendikbud, Konsep Dan Pedoman Penguatan Pendidikan Karakter (Jakarta: Kementerian Pendidikan dan Kebudayaan Republik Indonesia, 2016), p. 9. 
is qualitative research. Qualitative research according to Moleong "is research that aims to understand the reality experienced by research subjects such as perceptions, behaviors, actions holistically, and by way of description in the form of words and language, in a special natural context and by utilizing various methods. natural". ${ }^{7}$ Researchers used descriptive qualitative methods, by analyzing existing information data, based on facts in the field.

\section{RESULTS AND DISCUSSION}

\section{Implementation of Character Education}

After going through the planning process for the character education program, it is continued with the implementation process or implementation in the classroom. In the implementation of the character education program, it is adjusted to the plans that have been prepared so that the objectives of Character Education in Islamic Religious Education Subjects are achieved properly.

The implementation of Character Education in Islamic Religious Education Subjects in the class of SMA Negeri 1 Benteng, Selayar Islands Regency is prepared based on a program plan, both program objectives, time, place and so on. This applies to all school programs including the implementation of character education. The implementation of Character Education in Islamic Religious Education Subjects in the class of SMA Negeri 1 Benteng, Selayar Islands Regency is carried out in Islamic Education learning activities as follows:

Classroom learning activities carried out by the school on a regular and scheduled basis, which must be followed by every student. The character education program contains various activities to improve Graduate Competency Standards through the Basic Competencies possessed by students which

${ }^{7}$ Lexy J. Moleong, Metodologi Penelitian Kualitatif(Bandung: Remaja Rosdakarya, 2010), p. 6. 
are carried out in the class of SMA Negeri 1 Benteng, Selayar Islands Regency covering continuously every day according to the academic calendar.

The application of character education in the subject of Islamic Religious Education in the class of SMA Negeri 1 Benteng, Selayar Islands Regency was integrated into the subject of Islamic Religious Education and then developed in the learning session in the class on the subject of Islamic Religious Education in the class of SMA Negeri 1 Benteng, Selayar Islands Regency which includes activities introduction, core activity, closing activity, and learning assessment. Research through interviews, observation, and documentation review is described as follows:

\section{Preliminary activities}

Preliminary activities in the application of character education in Islamic Religious Education subjects in the class of SMA Negeri 1 Benteng, Selayar Islands Regency in learning are activities to open lessons which are the efforts of Islamic Religious Education teachers to create a mentally prepared atmosphere and raise the attention of students to focus on what will be studied. .

The implementation of character education in Islamic Religious Education subjects in the class of SMA Negeri 1 Benteng, Selayar Islands Regency, in learning related to preliminary activities can be known through interviews, observations, and documentation studies.

The author interviews with Islamic Religious Education teachers at SMA Negeri 1 Benteng, Selayar Islands Regency on learning, as follows:

"In the preliminary activity I still guided the lesson plan that the initial activity lesson plan included praying, apperception, conveying competence, lesson objectives by stating specifically and briefly in order to allow students to get a clear picture of the value of character education being studied, especially religious, nationalist values., independent, mutual cooperation, and integrity 
and the way to be taken in studying learning materials. In addition, giving to arouse curiosity, pay attention to class management and student management. For example, moving the seat of students who always bother friends.

To strengthen the explanation of the previous informant, the researcher continued the interview with the Islamic Religious Education teacher.

In the introduction, learning is carried out by stating the objectives and boundaries of the task, suggesting the steps to be taken, reminding the main problems to be discussed, and asking relevant questions and the material to be studied, as well as making lesson links by connecting the material being studied. students have mastered the material to be delivered. Of course I did not forget to convey the values of gotong royong, namely helping each other in terms of goodness."9

The results of the study through interviews with teachers and students, in accordance with the results of observations. This shows that the initial learning activities went well and in accordance with the RPP that had been prepared by the Islamic Religious Education teacher at SMA Negeri 1 Benteng, Selayar Islands Regency.

In order for the research data to be more accurate, the researchers conducted observations in the classroom when the learning process began, it was identified that the teacher carried out early learning activities by implementing character education in accordance with the lesson plans that had been prepared by the Islamic Religious Education teacher which was integrated through the development of teaching materials oriented to character education.

For example, Islamic Religious Education teachers are seen to instill religious values in learning, because at the beginning of learning Islamic Religious Education teachers

${ }^{8} \mathrm{Hj}$. Andi Kartini, Teacher, Interview, Selayar, 19 July 2021.

${ }^{9}$ Bau Siah, Teacher Interview, Selayar, 15 July 2021. 
always give greetings and students are accustomed to standing and answering greetings. This is also done when the learning process is complete. After the students answer the greetings and then the students return to their seats, the Islamic Religious Education teacher always invites students to read a prayer, the teacher exhorts the students to always carry the Koran, and the teacher often asks one of the students to read some verses of the Koran. led by a student who is rotated every hour of Islamic Religious Education lessons. Reading the verses of the Koran at the beginning of each lesson takes approximately 5-7 minutes.

In the results of observations of Islamic Religious Education teachers at SMA Negeri 1 Benteng, Selayar Islands Regency applying character education at the beginning of learning, it is proven that the teacher conveys religious character values, including tolerance towards other religions, living in harmony, love of peace, absence of violence in religion, sincerity, do not impose their will, love the environment, and others. Religious values are character values related to God. Someone in implementing and understanding the values of life in accordance with their respective beliefs. In addition, in everyday life, words and actions are sought based on religious values and teachings.

Islamic Religious Education teachers apply the value of honesty in learning Islamic Religious Education, the authors make observations regarding the efforts of teachers in character education by instilling honesty values in students. For example, in the early activities of teaching Islamic education teachers often tell stories about honest people, the importance of honesty in everyday life, and the commandment to apply and tell the truth in Islam. ${ }^{10}$

After being observed when learning took place in class $\mathrm{X}$, the researchers looked at the documentation of Islamic Religious Education teachers related to the document

${ }^{10}$ Observation, Selayar, 20 July 2021. 
instilling religious values in the lesson plans which contained the implementation of learning including the initial activities of learning, namely greeting, reading prayers and reading several verses of al-Qur'an. Qur'an. ${ }^{11}$

During observations in class XII, the Islamic Religious Education teacher at SMA Negeri 1 Benteng, Selayar Islands Regency applied character education at the beginning of learning, this was according to the results of the teacher's observations conveying to students the value of the character of nationalism, for example, the teacher conveyed how to behave, act, and think that showed togetherness, democracy, unity and integrity, as well as placing the interests of the nation and state above the interests of oneself and the group, also conveyed appreciation for the services of heroes, respect for cultural, ethnic and religious diversity, using domestic products, and memorizing national anthems.

The results of the observation show that Islamic Religious Education teachers at SMA Negeri 1 Benteng, Selayar Islands Regency instill the value of love for the homeland to students by providing an explanation at the beginning of learning about the importance of a student having a love for his homeland because they are the next generation who will build the nation to be better. good again. Furthermore, Islamic Religious Education teachers apply the value of the national spirit to students, the results of observations show that teachers often instill the values of the national spirit by conveying the purpose of the national spirit so that students feel they have the desire to become the next young generation who have the ability to build their nation. form of application of nationalist character education. ${ }^{12}$

The researcher continued to observe in different meetings related to the implementation of character education. The observation results show that Islamic Religious Education teachers at SMA Negeri 1 Benteng,

${ }^{11}$ Observation, Selayar, 20 July 2021.

${ }^{12}$ Observation, Selayar, 20 July 2021. 
Selayar Islands Regency instill the value of tolerance, because in learning teachers often convey the importance of tolerance in everyday life because it will have a positive impact on the formation of an environment in which there are students who understand each other. each other and respect each other. ${ }^{13}$

Furthermore, the researchers examined the documentation of the implementation of character education at the beginning of learning, it was true because in the lesson plans prepared by the teacher there was a learning development that contained character values, namely religious, nationalist, independent, mutual cooperation, and integrity. For example, the cultivation of tolerance values is supported by the teacher's documentation contained in the teacher's RPP which contains subject matter relating to the importance of tolerance in coexistence which requires mutual tolerance of each other's interests while still paying attention to other aspects such as maintaining trust and sticking to one another. stick to religion. ${ }^{14}$

Based on the results of observations regarding the teacher's efforts in implementing character education by applying the value of friendship and communicativeness, it shows that the teacher provides an explanation when learning that a sense of brotherhood must be grown by applying the habit of communicating with friends and with the surrounding environment. ${ }^{15}$ Due to frequent conversations and exchanging opinions, it will indirectly foster the value of friendship between students with each other. Togetherness is what will later play a role in shaping the character of the mutual cooperation of students.

The implementation of character education in Islamic Religious Education subjects at SMA Negeri 1 Benteng, Selayar Islands Regency at the beginning of the lesson went

${ }^{13}$ Observation, Selayar, 20 July 2021.

${ }^{14}$ Observation, Selayar, 20 July 2021

${ }^{15}$ Observation Selayar, 20 July 2021. 
well which was carried out according to the plans that had been prepared in the form of lesson plans. It is said to be going well because the data found in the field match the results of interviews, observations, and the results of the study of related documentation.

\section{Core activities}

The core activities in the application of character education in Islamic Religious Education subjects at SMA Negeri 1 Benteng, Selayar Islands Regency are identified through interviews, observations, and documentation review as follows:

\section{a. Mastery and Development of Study Materials}

Mastery and development of subject matter by Islamic Religious Education teachers at SMA Negeri 1 Benteng, Selayar Islands Regency, namely all those related to the subject matter taught to students, which have been prepared by the teacher.

Researchers interviewed the deputy head of the curriculum section of SMA Negeri 1 Benteng, Selayar Islands Regency, as follows:

"Every meeting with teachers at this school I always say that mastery of subject matter is mandatory for all teachers. I saw that the Islamic Religious Education teachers here mastered the subject matter, it was proven when I did class observations when the Islamic Religious Education teachers carried out the lessons, they seemed to be very well versed in the material, and in accordance with the lesson plans that had been prepared. In relation to the application of character education, Islamic Religious Education teachers deal with character values as described by Islamic Religious Education teachers in the classroom regarding the values of religious, nationalist, independent, mutual cooperation, and integrity character. ${ }^{16}$

16Andi Muhsin, vice principal, Selayar, 19 July 2021. 
One of the things done by Islamic Religious Education teachers in developing learning materials at SMA Negeri 1 Benteng, Selayar Islands Regency as stated by Islamic Religious Education teachers is as follows:

"In outlining subjects not only directly on the subject matter, but also describing things that are closely related to character values and Islamic religious values and developing subject matter is carried out using efficient time because time or class hours are very limited. Some of the development materials are described in the lesson plans, some are not explained because the lesson plans are also limited. But in its application we pay attention to the allocation of time, such as the value of caring for others, independent character is explained and applied directly in the learning process. Likewise, nationalist values are implemented to develop learning by adjusting the learning materials discussed. For example, if it is explained that nationalist values coincide with the commemoration of national holidays, then I will intersperse them with material about bubbul wathan minal faith. I understand them that Indonesia's independence was thanks to the struggle of the Muslims. When you look at the history, when you fight against the invaders, what you shout is Allahu Akbar. This means that it is the Muslims who are fighting for independence. Then the students are encouraged so that this independence is filled with the bubbul wathan. From there, I awakened the students' spirit of nationalism by giving lectures according to the topic". ${ }^{17}$

Based on the results of the interviews above, it shows that not all Islamic Religious Education teachers develop subject matter in intracurricular activities, not because they are unable but because of the limited time allocation factor. An initiative taken by Islamic Religious Education teachers at

${ }^{17} \mathrm{Hj}$. Andi Kartini, Teacher Interview, Selayar, 19 July 2021. 
SMA Negeri 1 Benteng, Selayar Islands Regency in overcoming the constraints of limited time allocation is activating extracurricular activities.

Islamic Religious Education teachers at SMA Negeri 1 Benteng, Selayar Islands Regency have the ability to connect one material to another, this is done so that students gain more knowledge about learning, and to facilitate students' understanding because the teacher connects one subject matter to another. with other subjects. One of the teaching principles is the correlation principle, namely the teacher shows the relationships between subject matter, in this case the Islamic Religious Education teacher at SMA Negeri 1 Benteng, Selayar Islands Regency integrates character development with the substance of contextual Islamic Religious Education subjects. Contextual in question starts from learning planning to assessment.

The results of observations regarding the efforts of teachers in implementing character education through learning Islamic Religious Education by applying the value of caring for others and the environment that Islamic Religious Education teachers at SMA Negeri 1 Benteng, Selayar Islands Regency provide an overview of the importance of caring for social life as social beings and caring for the environment. as humans who inhabit an environment. It is this concern that builds the positive character of students so that students always keep their environment clean and maintain their communication and good relations with the people around them. In the learning process, the teacher directly guides students on how to help others, directs the attitude of caring for the environment, such as maintaining the cleanliness of the classroom and the school environment.

Observation results show that Islamic Religious Education teachers at SMA Negeri 1 Benteng, Selayar Islands Regency often apply an independent attitude to students by explaining independent attitudes and getting students to do things without the help of others so that an attitude of 
independence towards students is embedded as well as increasing students' self-confidence. not to depend on others. $^{18}$

Islamic Religious Education teachers at SMA Negeri 1 Benteng, Selayar Islands Regency apply character education to students through learning Islamic Religious Education by teaching religious values to be closer to the creator, instilling the value of tolerance so that they can understand each other, discipline to form a more organized personality, a hard working attitude so as not to give up easily in achieving goals, afar's creative attitude always grows and finds new ideas, and independence that can make participants able to do their jobs without expecting help from others. students' self-confidence can also develop to become better individuals.

Researchers conducted a study of documentation related to the development of Islamic Religious Education learning. Islamic Religious Education teachers at SMA Negeri 1 Benteng, Selayar Islands Regency have integrated character education in Islamic Religious Education subjects into each subject. These character values are listed in the syllabus and lesson plans and are applied in class. Learning activities in character education of Islamic Religious Education teacher students at SMA Negeri 1 Benteng, Selayar Islands Regency use active learning approaches such as contextual learning approaches, cooperative learning, and problem-based learning.

The results of observations regarding the application of character education through learning Islamic Religious Education by applying democratic values to students, show that Islamic Religious Education teachers at SMA Negeri 1 Benteng, Selayar Islands Regency, apply democratic values in learning, namely conveying the importance of democracy in people's lives, because by having a democratic character can create a safe life and give birth to unity. ${ }^{19}$

${ }^{18}$ Observation, Selayar, 22 July 2021.

${ }^{19}$ Observation, Selayar, 22 July 2021. 
Furthermore, the author observes the teacher's efforts in implementing character education through learning Islamic Religious Education in the classroom by teaching the spirit to always have a work spirit. in achieving goals. In addition, the Islamic Religious Education teacher at SMA Negeri 1 Benteng, Selayar Islands Regency gave assignments to students to measure the enthusiasm of students. ${ }^{20}$

Observations on the efforts of teachers in implementing character education through Islamic Religious Education learning by awakening the creativity of students, namely Islamic Religious Education teachers carrying out various activities in interesting and useful learning such as holding calligraphy competitions and skills to wear hijab for women, in addition to the direct practice of Islamic Religious Education teachers also often explain the benefits of creativity in social life, because creativity can support success and independence. $^{21}$

The results of observations in the application of character education through learning Islamic Religious Education by applying character values respecting achievement, Islamic Religious Education teachers at SMA Negeri 1 Benteng, Selayar Islands Regency, carry out various interesting and useful activities such as holding competitions that show students' learning achievements with the aim of raising enthusiasm for learning, conducting several experiments in learning in order to find new ideas so that students' learning achievements are appreciated by their friends. ${ }^{22}$

This attitude indirectly shapes the character of students for the better. In addition to their sense of responsibility, students also have sensitivity to the environment, love for their nation with the spirit of nationalism, friendship, and a sense of democracy. Where

\footnotetext{
${ }^{20}$ Observation, Selayar, 23 July 2021.

${ }^{21}$ Observation Selayar, 23 July 2021.

${ }^{22}$ Observation, Selayar, 23 July 2021.
} 
students can share, help each other as a manifestation of the results of the application of character education through learning Islamic Religious Education at SMA Negeri 1 Benteng, Selayar Islands Regency.

Based on data collection through interviews, observations, and documentation review, it provides an understanding that Islamic Religious Education teachers at SMA Negeri 1 Benteng, Selayar Islands Regency master the material and develop subject matter to provide added value that can lead students to achieve character education goals, namely to become human. who believe and fear Allah swt and have noble character, in accordance with the goals of national education.

\section{b. Application of Learning Method}

The learning method implies a way, a pattern, or the strategic steps undertaken by the Islamic Education in SMA 1 Fortress Islands District Selayar to mem - hearten and learners to follow and understand rangakaian learning process according the subject matter presented, in order to achieve the goal character education through learning Islamic Religious Education at SMA Negeri 1 Benteng, Selayar Islands Regency.

To find data on the application of character education through learning Islamic Religious Education in SMA Negeri 1 Benteng, Selayar Islands Regency, in terms of the application of learning methods, the researchers conducted interviews and observations. Researchers interviewed teachers of Islamic Religious Education at SMA Negeri 1 Benteng, Selayar Islands Regency as follows:

"I think the application of character education through Islamic Religious Education learning requires the right method. That is why I apply various methods and it has been determined in the lesson plans, taking into account the condition of the subject matter adjusted to class conditions and available time conditions, but the 
most frequently applied are lecture and demonstration methods. ${ }^{23}$

"Actually I apply various methods but the most frequently applied are lectures and discussion groups". ${ }^{24}$ "If I apply various methods, the methods that are often applied include; lecture method or story method, question and answer method, assignment method, discussion method, demonstration method, group work method, and practice method (drill). The formulation of the method is adjusted to the subject matter to be taught and the learning conditions of students, and the learning method has been formulated in the lesson plan. However, what I use most often is the lecture method, the question and answer method, and the assignment method. ${ }^{25}$

Based on the results of several interviews with Islamic Religious Education teachers at SMA Negeri 1 Benteng, Selayar Islands Regency above, it shows that teachers apply learning methods according to the lesson plans and apply various methods, although the most frequently applied is the lecture method, because all teachers apply lecture method.

Regarding the application of the learning method, the researcher conducted interviews with the principal of SMA Negeri 1 Benteng, Selayar Islands Regency:

"In the formulation of learning methods the teacher adapts to the subject matter to be taught and the condition of the ability of students, consideration of time allocation and the state of the school environment"26

Sometimes teachers appear to teach better by using the lecture method than by giving students the freedom to

${ }^{23} \mathrm{Hj}$. Sri Samriana, Teacher, Interview, Selayar, 21 July 2021.

${ }^{24} \mathrm{Hj}$. Andi Kartini, Teacher, Interview, Selayar, 19 July 2021.

${ }^{25}$ Bau Siah, Teacher, Selayar, 22 July 2021.

${ }^{26} \mathrm{Hj}$. Basse Salma, School Principal, Interview, Selayar, 19 July 2021. 
work. Sometimes a teaching material is better delivered with a combination of several methods than with only one method. On that basis, the teacher's task in implementing character education in Islamic Religious Education subjects at SMA Negeri 1 Benteng, Selayar Islands Regency is to choose the right method to be used in creating the learning process.

The application of learning methods in the implementation of character education in the subject of Islamic Education in SMA 1 Fortress District Selayar Islands is influenced by many factors, including the nature of the learning objectives to be achieved, the need for memper - rich learning experiences such as increasing the intrinsic and extrinsic learners, learning abilities covered in assignments, time management, selection of what to deliver, knowing the strengths of teachers as effectively as possible, and setting appropriate priorities.

\section{CONCLUSION}

The implementation of character education in Islamic Religious Education subjects in the class of SMA Negeri 1 Benteng, Selayar Islands Regency is guided by the Learning Implementation Plan (RPP) which includes first preliminary activities, Islamic Religious Education teachers create a mentally prepared atmosphere and raise the attention of students to focus on learning through learning. providing motivation for students to convey the values of character education; The two core activities of Islamic Religious Education teachers develop material by integrating character education values into learning materials, in the application of the method the teacher makes habituation in the classroom in which there are religious, independent, nationalist, mutual cooperation, and integrity values while the use of teacher media Islamic Religious Education uses visual media, audio visual and learning media based on Information Technology Communication (ITC); the three closing activities, the Islamic Religious Education teacher conducted a post-test both 
orally, in writing, especially those related to the value of character education; and the fourth assessment of learning Islamic education teachers assess and clicking - the evaluation of learning outcomes by measuring the ability of cognitive, affective and psychomotor learners.

The supporting and inhibiting factors for the implementation of character education in Islamic Religious Education subjects at SMA Negeri 1 Benteng, Selayar Islands Regency, the first supporting factors are the collaboration of Islamic Religious Education teachers with teachers in other fields of study by consulting the condition of students, conducting religious extracurricular activities (weekly, monthly recitations)., and the Ramadhan Islamic Boarding School), and fostering students through the provision of advice, as well as fostering students through habituation and supervision; The two inhibiting factors are the limitations of reference books in the school library, limited funds, lack of parental attention, the occurrence of a global moral crisis that affects the moral crisis of students.

\section{REFERENCES}

Abdullah, M. Yatimin. Moral Studies in the Perspective of the Qur'an. cet. XI; Jakarta: Amzah, 2017.

Abu 'Abdillah Muhammad bin Ismail al-Bukhari, Sahịh alBukhārí, Juz 1 . cet. I; Beirut: Dār Ṭuruq al-Najah, $1422 \mathrm{H}$.

Alim, Muhammad. Islamic education; Efforts to Formation of Muslim Thought and Personality. cet. XI; Bandung: Rosdakarya Youth, 2016.

Alma, Buchari. Professional Teachers Mastering Methods and Skilled in Teaching. cet. XII; Bandung: Alphabeta, 2019. 
Al-Qur'an and the Translation of the Ministry of Religion of the Republic of Indonesia., (Bandung: PT. Syamil Cipta Media, 2005).

Anwar, Rosihon. Akidah Morals and Its Problems. cet. XI; Jakarta: Amzah, 2017.

Asmaran AS, Introduction to Moral Studies. cet. XII; Jakarta: Raja Grafindo Persada, 2012.

Burn, Abu. The Concept of Application of Islamic Sharia in the Prevention of Deviant Behavior in Adolescents. cet. I; Jakarta: Gema Insani Press, 2009.

Damopolii, Muljono. Modern Islamic Islamic Boarding School IMMIM Modern Muslim Printer. cet. I; Jakarta: PT RajaGrafindo Persada, 2011.

Danim, Sudarwan and Khaeril, Educational Profession. cet. II; Bandung: Alfabeta, 2011.

Daradjat, Zakiah. Religious and Moral Education for Children and Youth. cet. I; Jakarta: Logos Discourse on Science, 2001.

Darmadi, Hamid. Basic Ability to Teach Conceptual Basis and Implementation. cet. IX; Bandung; Alphabet, 2019.

Daulay, Heydar Putra. Islamic Education in the National Education System in Indonesia. cet. XI; Jakarta: 2014.

Djatnika, Rachmat. Islamic Ethical System; Noble Morals. cet. XII; Jakarta: Panjimas Library, 2016.

Eggen, Paul and Don Kauchak. Educational Psychology Windows on Classrooms. Columbus: University of North Florida, 2017.

Fathurrohman, Pupuh and M. Sobry Sutikno. Teaching and Learning Strategies Through Planting General Concepts \& Islamic Concepts. cet. IV; Bandung: Refika Aditama, 2010.

Francesco Sofo. Human Resource Development, Perspective, Roles and Practice Choice. Business and Professional Publishing, (Warriewood, NWS, 2015), p. 123.

Getteng, Abd. Rahman. Towards Professional and Ethical Teachers. cet. VII; Yogyakarta: Grha Guru, 2012. 
Gunawan, Heri. Character building; Concept and Implementation. cet. II; Bandung: Alfabeta, 2012.

Ilyas, Yunahar. Morals Lecture. cet. XIV; Yogyakarta: Institute for the Study and Practice of Islam, 2015.

Imam Ibn Husain Muslim bin Hajjaaj Ibn Muslim al-Qusyairi al-Naisabuuri, al-Jaami Sahih, al-Musamma Sabih Muslim, Juz VIII (Bairut: Daar al-Ma'aarif, t.th.).

Kelven Hall, Readings in Value Development (New Yersey: Paulist Press, 1982).

Ministry of Religion of the Republic of Indonesia, Government Regulation of the Republic of Indonesia Number 55 of 2007 concerning Religious Education and Religious Education . Jakarta: Directorate of Islamic Religious Education, 2011. 